American Journal of Applied Sciences 7 (4): 562-567, 2010

ISSN 1546-9239

(C) 2010Science Publications

\title{
Motivators, Barriers and Concerns in Adoption of Electronic Filing System: Survey Evidence from Malaysian Professional Accountants
}

\author{
${ }^{1}$ Ming-Ling Lai and ${ }^{2}$ Kwai-Fatt Choong \\ ${ }^{1}$ Faculty of Accountancy, Accounting Research Institute, \\ Universiti Teknologi MARA, Shah Alam, Malaysia \\ ${ }^{2}$ Faculty of Business and Accountancy, University of Malaya, Kuala Lumpur, Malaysia
}

\begin{abstract}
Problem statement: Worldwide, electronic filing (e-filing) system and its' adoption has attracted much attention, however, scholarly study on accounting professionals' acceptance of e-filing system is scant. Approach: This study aimed (i) to examine factors that motivated professional accountants to use e-filing (ii) to solicit their usage experience and (iii) to assess the barriers to adoption and other compliance considerations. The questionnaire survey was administered on 700 professionals from tax practice and commercial sectors who attended "Budget 2008" Tax Seminars, organized by the Malaysian Institute of Accountants in Peninsular Malaysia. In total, 456 usable responses from accounting and tax professionals were collected and analyzed. Results: The survey found out of 456 respondents, just $23.7 \%$ had used e-filing in 2007 to file personal tax return forms. Majority of the e-filers opted to use e-filing for the sake of convenience (55.8\%), in faith to get faster tax refund $(16.8 \%)$ and speed of filing $(15.9 \%)$. For those who did not use e-filing, the key impediments were concerned over the security and did not trust of e-filing system. Some $(4.8 \%)$ were unable to access to the e-filing website. Overall, just $26.1 \%$ of the professionals surveyed had confidence in the IRBM in managing the e-filing system successfully. Majority (41.2\%) thought that 'speedy tax refund' to be the most desirable incentive to motivate individuals to use e-filing. Conclusion: As the IRBM is counting on professional accountants to promote the usage of e-filing system, this study provided important insights to the IRBM to developing marketing and business strategies to motivate professional accountant in business to use e-filing in order to accelerate the diffusion of e-filing system in a developing country like Malaysia.
\end{abstract}

Key words: Electronic tax filing, motivators, barriers, professional accountant, Malaysia

\section{INTRODUCTION}

Worldwide, since the 1990s, in order to achieve greater tax administrative and compliance efficiency, several tax authorities had progressively harnessed the power of Internet technologies by embracing an electronic tax filing (e-filing) system (ACCA, 2002; ETAAC, 2002). In most countries, e-filing is not mandatory rather it is offered as an option to taxpayers and their tax representatives, as a result, worldwide, several studies found tax users' resistance to use e-filing system remains a widespread problem (ACCA, 2002; ETAAC, 2007; Hansford et al., 2006; Hung et al., 2006; Tan et al., 2005). Although, the e-filing system may offer potential benefits to improve administrative compliance efficiency, the benefits gained may be obstructed by tax users' unwillingness to accept and use the new tax technology. In essence, the move to adopt an e-filing system is neither hassle free nor well accepted by all tax parties, particularly the tax agents and professionals. However, tax professionals' acceptance is deemed a necessary condition for the success of the e-filing system. In developed countries like Australia, Canada, the UK, US and New Zealand, several studies have been conducted to examine tax practitioners' acceptance of e-filing (ACCA, 2002; ETAAC, 2002; Hansford et al., 2006; Russell Marketing Research, 2003). For example, in the US, it was found that American tax professionals vary widely in their attitudes, technology readiness, acceptance and utilization of e-filing technologies (ETAAC, 2002). In addition, the lack of perceived benefits, cost of compliance, lack of willingness to learn and perceived insecurities and misconceptions of the e filing service have impeded the tax professionals in the US from expending the resources to get involved (ETAAC,

Corresponding Author: Ming-Ling Lai, Faculty of Accountancy, Accounting Research Institute,

Universiti Teknologi MARA, Shah Alam, Malaysia 
2002; 2007). In a similar vein, in the UK, the ACCA survey found that professional accountants have shown no confidence in online tax filing (ACCA, 2002). The Electronic Tax Administration Advisory Committee (ETAAC) is recommending to mandate certain taxpayers and tax practitioners to e-file personal and business tax returns in the US (ETAAC, 2007; 2009). In Singapore, study indicated that the government needs to restore public trust in e-filing and to blend sociopolitical strategies, technology and taxation together (Tan et al., 2005).

On 10th February 2006, the Inland Revenue Board Malaysia (IRBM) had streamlined the tax administration policies to embrace an e-filing system. With the e-filing system, Malaysian taxpayers and tax agents can file income tax returns electronically via the enabling Internet technologies, rather than through mail or physical visits to the tax office. This may eventually make the art of filing tax returns as easy as possible. In the first year of implementation of e-filing system for individual taxpayers, in spite of the extension of the tax filing deadline by one month and a promise to get faster tax refund for e-filers; just more than 120,000 out of 4 million individual taxpayers opted to use e-filing; which represented only $3 \%$ of the total individual taxpayers (The Star, 2006a). It was reported that discomfort about e-filing technology and perceived insecurity of e-filing (Fatimah and Lai, 2008; Lai, 2006a) as well as lack of internet self-efficacy and skills are potential threats to the adoption of e-filing in Malaysia (The Star, 2006b). The number of taxpayers using e-filing had increased gradually from 538,558 (in 2007 ) to 881,387 in 2008 (The Star, 2009); however, several studies found e-filing has yet to gain momentum in Malaysia, especially the tax professional groups, although they are the intended users, majority have not used e-filing (Fatimah and Lai, 2008; Lai et al., 2005). In essence, studies found that professional accountants (i.e., the professional tax preparers/practitioners) represent both a means of increasing compliance and also potentially a threat to compliance (Klepper and Nagin, 1989) and tax professionals are in a position to exercise a strong and direct influence on the tax administration and compliance processes (Erard, 1993; Newsberry et al., 1993).

Empirical study provided the insights that that an e-filing system can only work effectively with the assistance and cooperation of tax preparers/professionals (Kahan, 1999). To be accepted, an e-filing system needs to be perceived by tax professionals as possessing sufficient usability for supporting or enhancing their core competency, productivity and business performance in providing tax service to clients. At a minimum, an e-filing system must be capable of helping the tax professionals to complete tax preparation and filing processes quicker than the traditional paper filing method. If using the efiling system can increase the speed of submitting a tax return, it will enhance job efficiency, save business time and cost (Lee et al., 2005). On the other hand, several studies found the applicability of modified technology acceptance model in predicting tax users' acceptance of e-filing system in Taiwan (Hung et al., 2006; Fu et al., 2006; Chang et al., 2005), United States (Schaupp and Carter, 2008) and India (Ojha et al., 2009). Hence, there is a practical need for the e-filing system to be accepted by the tax practitioners in order to boost the success rate of the e-filing system. However, traditionally, accountants and tax professionals were slow to adopt newer technologies until their worth was proven and their reliability was fully documented (Kocakulah and Grower, 2000; Skillman, 1998). However, at the time of study, little is known about Malaysian professional accountants' response towards e-filing. There are several concerns. Are Malaysian professional accountants willing to use the new tax technology? What are their e-filing experiences? What are the compelling incentives that the IRBM could offer to motivate professional accountants to use e-filing? What are the potential compliance issues that may arise pertaining to the e-filing system in the Malaysian tax setting? The move of the IRBM to adopt the e-filing system, plus the lack of empirical tax research from the perspective of professionals shaped the motivation for this study. The research objectives are presented next.

Research objectives: The objectives of the study are (i) to examine factors that motivated professional accountants to use e-filing (ii) to solicit their usage experience and (iii) to assess the barriers to adoption and other compliance considerations from the perspectives of professional accountants.

\section{MATERIALS AND METHODS}

A questionnaire survey was used to collect data. The target respondents were professional accountants in Malaysia; the professional accountants are the study subjects because they are the intended and potential users of e-filing system. The tax authorities are counting on them to use e-filing and to accelerate the diffusion of e-filing technologies nationwide. In the months of September and October 2007, Malaysian Institute of Accountants (MIA) had organized several "Budget 2008 Tax Seminars" in Peninsular Malaysia. With the assistance from the MIA organizing committees, questionnaires were administered on 700 
participants who attended "Budget 2008 Tax Seminars" in Peninsular Malaysia. Responses from non professionals were excluded from data analysis, in total, 456 usable responses from professional accountants were analyzed and reported. All of them had professional qualification from the accounting bodies, such as the Association of Certified Chartered Accountants, Certificate of Public Accountant, Australia, Chartered Tax Institute of Malaysia, Cost and Institute Management Accountants and Malaysian Institute of Certified Public Accountants.

\section{RESULTS AND DISCUSSION}

Data analysis:

The respondents' profiles: Table 1 presents the respondents' profiles. Out of 456 respondents, majority of them were from central region (74.1\%), 10.1\% from Northern region and $15.8 \%$ from the Southern region of Malaysia. About $39 \%$ of them were males and $57 \%$ aged between 31 and 40 years old. In term of ethnicity, Chinese were the most notable participants, making up about $93.4 \%$. All of the respondents possessed professional qualifications from various professional bodies such as the Association of Chartered Certified Accountants, Malaysian Institute of Certified Public Accountants, Malaysian Institute of Taxation and Certified Practicing Accountants, Australia. About $63.2 \%$ of them filed Form BE in 2007, which indicated that they are salaried individuals. The remainders (36.8\%) filed Form B in 2007; hence indicates that $36.8 \%$ of the survey respondents were professional accountants in business or in practice.

Table 1: The respondents' profiles

\begin{tabular}{lll} 
& $\begin{array}{l}\text { Profiles of those who } \\
\text { had e-filed successfully }\end{array}$ & Frequency (\%) \\
\hline $\begin{array}{l}\text { Location } \\
\text { Central region }\end{array}$ & $79(69.9)$ & $338(74.1)$ \\
$\begin{array}{l}\text { Northern region } \\
\text { Southern region }\end{array}$ & $18(16)$ & $81(10.8)$ \\
Gender & $16(14.2)$ & $37(8.1)$ \\
Male & & \\
Female & $51(45.1)$ & $177(38.8)$ \\
Age & $62(54.9)$ & $279(61.2)$ \\
$\leq 30$ & & \\
$31-40$ years old & $23(20.4)$ & $88(19.3)$ \\
$41-50$ years old & $66(58.4)$ & $260(57)$ \\
$\geq 50$ years old & $19(16.8)$ & $67(14.7)$ \\
Ethics & $5(4.4)$ & $41(9)$ \\
Chinese & & $426(93.4)$ \\
Malay & $105(92.9)$ & $9(2)$ \\
Indian & $5(4.4)$ & $11(2.4)$ \\
Others & $2(1.8)$ & $10(2.2)$ \\
Tax return filed in 2007* & $1(0.9)$ & $288(63.2)$ \\
Form BE & $72(63.7)$ & $168(36.8)$ \\
Form B & $41(36.3)$ & $456(100)$ \\
Total & $113(24.7 \%)$ & file Form BE, \\
$*:$ In Malaysia, salaried & taxpayers are required & to \\
whilst, individuals with business income are required to file Form B &
\end{tabular}

Profiles of those who had e-filed successfully: Out of the 456 survey respondents, just $24.7 \%$ (113 out of 456) had attempted e-filing since it was launched in 2006 (Table 1, row 7, column 2). They are termed as e-filers. Notably, majority of the e-filers are from the central region, i.e., the capital city of Malaysia and the state of Selangor. Majority of e-filers are Chinese $(92.9 \%)$ and aged between 31 to 40 years old $(58.4 \%)$. Female efilers appears to be more than males counterparts, nonetheless, at $95 \%$ confidence level, a chi-square test shows there is no significant difference in gender among the e-filers.

E-filers' experience: To further probe the issue, we asked the e-filers where they did e-filing. The survey found $48 \%$ of e-filers did it from home, $38 \%$ from their office and 14\% from the IRBM's office. In respect of the time taken to e-file successfully, $35.4 \%$ of the efilers indicated that they took less than $30 \mathrm{~min}, 47.8 \%$ took between $30 \mathrm{~min}$ to $1 \mathrm{~h}, 10.6 \%$ took between $1-2 \mathrm{~h}$ and $6.2 \%$ took more than $2 \mathrm{~h}$. The findings indicate that the duration to complete e-filing was rather long, it should be done within $15 \mathrm{~min}$. When asked about the overall experience of e-filing, Fig. 1 shows that $55.8 \%$ of e-filers found e-filing convenient and easy to use. About $7.1 \%$ found e-filing was good and pleasant. However, $31.9 \%$ of e-filers indicated that e-filing was not as good as they had expected and 5.3\% found efiling was unpleasant and tedious.

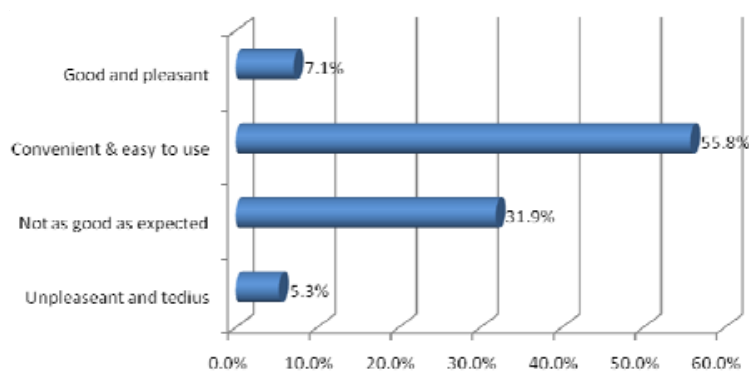

Fig. 1: E-filers overall experience of e-filing

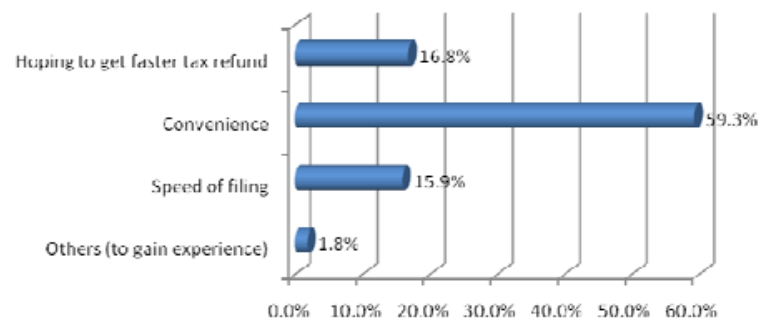

Fig. 2: Reasons for using e-filing 
With regards to reason for opting to use e-filing, the survey found $59.3 \%$ of the e-filers indicated that they chose e-filing over manual filing for the sake of convenience (Fig. 2). About $15.9 \%$ used e-filing for the speed of filing, whilst $16.8 \%$ e-filers were hoping to get faster tax refund. Notably, $6.2 \%$ opted to use e-filing in 2006, because extension of filing deadline was given in year 2006 for those who used e-filing. Merely 1.8\% tried e-filing to gain experience before introduce efiling to clients. Overall, the reasons for using e-filing are somewhat consistent with study of Fatimah and Lai (2008) when she surveyed the e-filing experience among members of Malaysian Institute of Taxation. Fatimah and Lai (2008) also found convenience, speed of tax filing and faster tax refund appeared to be the three most important considerations for Malaysian tax professionals to use e-filing.

Non E-filers: Reasons for not using e-filing: Out of 456 respondents, 343 respondents $(75.2 \%)$ preferred to use manual filing instead of e-filing. In this study, they are termed as non e-filers. To probe the issue further, we asked them why they preferred manual filing instead of e-filing. Figure 3 presents the findings. More than $25 \%$ of non e-filers indicated that they were concerned about the security of e-filing system. About $20.8 \%$ did not trust the e-filing system, some $11.8 \%$ of the non efilers indicated that they had no experience and knowledge to e-file. The plausible explanation is they were not technology savvy or lacked internet selfefficacy to use e-filing. Another $5.7 \%$ indicated that there is no incentive for them to use e-filing. About $4.8 \%$ had attempted to use e-filing but were unable to efile successfully, consequentially, they had to opt for paper filing at the end. Overall, the survey found reasons for not using e-filing are many.

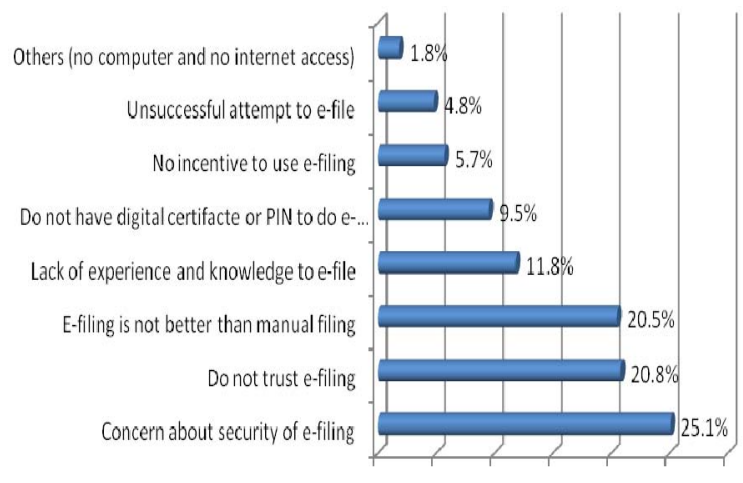

$0.0 \% \quad 5.0 \% \quad 10.0 \% \quad 15.0 \% \quad 20.0 \% \quad 25.0 \% \quad 30.0 \%$

Fig. 3 Reasons for not using e-filing in year 2007
Other findings: In turn, we solicited survey respondents' opinions on (i) intention to use e-filing in the future, (ii) what type of incentives that would motivate them to use e-filing, (iii) whether e-filing should be made mandatory and (iv) whether they have confidence in the IRBM in managing the e-filing system successfully. The findings as presented in Table 2 show that less than half $(48.7 \%)$ of the respondents had the intention to use e-filing in the future (Table 2, row 1, column 2). This result is not encouraging in view that the IRBM is counting on the tax professionals to accelerate the diffusion of e-filing technology. Merely $29.6 \%$ had the opinion that e-filing should be made mandatory and the reminders (70.4\%) thought otherwise. Notably, just $26.1 \%$ had confidence in the IRBM in managing e-filing successfully; whilst majority $(73.9 \%)$ had no confidence in the electronic administrative capability of the IRBM. This finding supports the assertion of Tan et al. (2005) that the government needs to restore public trust in e-filing as one of the e-government initiatives.

In respect of the type of incentives that will motivate the take up of the e-filing system, majority $(41.2 \%)$ of the respondents indicated that 'speedy tax refund' to be the most desirable incentive (Table 2, row 3 , column 2). This finding is somewhat consistent with Lai (2006b) when surveyed Malaysian tax practitioners' responses towards e-filing (Lai, 2006b). In addition, this study found $35.1 \%$ of the respondents' quest for 'special cash rebate' for those who use e-filing and $22.8 \%$ suggested 'extension of tax filing deadline' for those who used e-file would motivate the take up of efiling. Surprisingly, less than $1 \%$ suggested lucky draw prizes for those who e-filed. The plausible explanation is the professionals used e-filing because it is useful and easy to use instead of hoping to get 'lucky draw' prizes for early birds like what it was practiced in Singapore at the threshold of implementation.

\section{Table 2: Other findings}

\begin{tabular}{lc}
\hline Intent to use e-filing in the future & $222(48.7 \%)$ \\
Yes & $234(51.3 \%)$ \\
No & \\
E-filing should be mandatory & $135(29.6 \%)$ \\
Yes & $321(70.4 \%)$ \\
No & \\
Incentive that motivate the use of e-filing & $104(22.8 \%)$ \\
Extension of filing deadline for e-filers & $188(41.2 \%)$ \\
Faster tax refund if use e-filing & $160(35.1 \%)$ \\
Special cash rebate for e-filers & $4(0.9 \%)$ \\
Lucky draw prize for e-filers & $119(26.1 \%)$ \\
Confidence in the IRBM in managing e-filing successfully \\
Yes & $337(73.9 \%)$ \\
No & $456(100 \%)$ \\
Total & \\
\hline
\end{tabular}


It is worth noting here that the Inland Revenue Authority of Singapore (IRAS) used lucky draw prizes as an incentive to encourage individuals to take up efiling in the early years of implementation (IRAS, 2002). The list of e-filing lucky draw winners who won cash prizes in the "E-filing Lucky draw" were publicized on the IRAS websites to motivate taxpayers to take up e-filing (IRAS, 2002). Nonetheless, 'e-filing lucky draw' might appeal to ordinary taxpayers but not the professional accountants.

\section{CONCLUSION}

The issue of professional accountants' adoption of e-filing has attracted much attention; nonetheless, little study has been conducted to examine their usage and compliance considerations of the e-filing system. This study found e-filing has not gained momentum in Malaysia, especially with the professionals group. As professional accountants are the most important endusers, sufficient understanding of their usage experience, motivators, barriers and concerns would motivate usage and interactions among taxpayers, tax practitioners and the tax authorities, as well as to reduce the risk of user rejection.

The limitations of this study are firstly, it is a crosssectional study and secondly, only those professional accountants who attended the "Budget 2008" tax seminar were surveyed. Hence, limits the generalizability of the findings. Nonetheless, in considering that e-filing is the strategy taken by tax authorities around the world to enhance tax compliance and administrative efficiency, this study provide important insights to the tax authorities on motivators, barriers and concerns in adoption of e-filing system among professional accountants in business. The tax authorities ought to develop business and marketing strategy to accelerate the diffusion of e-filing system among professionals. Malaysian tax authorities need to work with software developer of the e-filing system to reducing and resolving reject issues. It is suggested that Malaysian tax authorities to emulate the US tax authorities to commission or to conduct tracer study on professionals (especially the tax preparers group) to understand them better. Future study can also be conducted to examine the impact of e-filing on tax practice and business.

\section{REFERENCES}

ACCA., 2002. ACCA members survey: Selfassessment. ACCA, pp: 1-20. http://www.accaglobal.com/pubs/general/activities/ library/other_issues/surveys/554500.pdf
Chang, I.C., Y.C. Li W.F. Hung and H.G. Hwang, 2005. An empirical study on the impact of quality antecedents on taxpayers' acceptance of internet tax filing systems. Govern. Inform. Q., 22: 389-410.

Erard, B., 1993. Taxation with representation: An analysis of the role of tax practitioners in tax compliance. J. Public Econ., 52: 163-197.

ETAAC., 2002. Electronic tax administration advisory committee: Annual report to congress. Electronic Tax Administration Advisory Committee (ETAAC).

ETAAC., 2007. Electronic tax administration advisory committee: Annual report to congress. Electronic Tax Administration Advisory Committee (ETAAC). http://apps.irs.gov/pub/irs-prior/p3415-2007.pdf

ETAAC., 2009. Electronic tax administration advisory committee: Annual report to congress. Electronic Tax Administration Advisory Committee (ETAAC).http://apps.irs.gov/pub/irs-pdf/p3415.pdf

Fatimah, A. and M.L. Lai, 2008. Embracing electronic tax filing: Survey evidence from members of Malaysian institute of taxation. Proceeding of the International Accounting and Business Conference 2008: Globalizing Business and Financial Integrity Towards Economics, Aug. 18-19, The Puteri Pacific, Johore Bahru. Malaysia.

Fu, J.R., C.K. Farn and W.P. Chao, 2006. Acceptance of electronic tax filing: A study of taxpayers' intentions. Inform. Manage., 43: 109-126.

Hansford, A., A. Lymer and C. Pilkington, 2006. IT adoption strategies and their application to e-filing self-assessment tax returns: The case of the UK. eJ. Tax Res., 4: 80-96. http://ideas.repec.org/p/nsw/discus/414.html

Hung, S.Y., C.M. Chang and T.J. Yu, 2006. Determinants of user acceptance of the egovernment services: The case of online tax filing and payment system. Govern. Inform. Q., 23: 97-122.

IRAS., 2002. List of e-filing lucky draw 2002 winners. IRAS. http://www.iras.gov.sg/press/PR2002/press05.htm

Kahan, S., 1999. Promoting e-filing. Pract. Account., 32: 69-73.

Klepper, S. and D. Nagin, 1989. The role of tax preparers in tax compliance. Policy Sci., 22: 167-194.

Kocakulah, M.C. and G.M. Grower, 2000. Modernizing the bureaucracy: Government information systems and technology. Natl. Public Account., 45: 24-25.

Lai, M.L., 2006a. Electronic tax filing system: Benefits and barriers to adoption of system. The Chartered Secretaries Malaysia. 
Lai, M.L., 2006b. Malaysian in-house corporate tax preparers and the electronic tax filing system. Tax National, 1st Quarter, pp: 20-25.

Lai, M.L., S.O. Siti Normala and M. Ahamed Kameel, 2005. Tax practitioners and electronic filing system: An empirical analysis. Acad. Account. Financ. Stud. J., 9: 93-107.

Lee, K.C., K. Melih, L. Sangjae, G.G. Lim, 2005. User evaluation of tax filing web sites: A comparative study of South Korea and Turkey. Online Inform. Rev., 22: 842-859.

Newsberry, K.J., P.M.J. Reckers and R.W. Wyndelts, 1993. An examination of tax practitioner decisions: The role of preparer sanction and framing effects associated with client condition. J. Econ. Psychol., 14: 439-452.

Ojha, A., G.P. Sahu and M.P. Gupta, 2009. Antecedents of paperless income tax filing by young professionals in India: an exploratory study. Transform. Govern. People, Process Policy, 3: 65-90.

Russell Marketing Research, 2003. Findings from the 2003 wave of the e-file practitioners' attitudinal tracking. Study.

RMR. http://www.irs.gov/efile/article/0,,id=118376,00.html
Schaupp, L. and L. Carter, 2008. The impact of trust, risk and optimism bias on e-file adoption. Inform. Syst. Front., 12: 299-309. DOI: 10.1007/s10796008-9138-8

Skillman, B., 1998. Fired up at the IRS. Account. Technol., 14: 12-20.

Tan, C.W., S.L. Pan and E.T.K. Lim, 2005. Towards the restoration of public trust in electronic governments: A case study of the e-filing system in Singapore. Proceeding of the 38th Hawaii International Conference on System Sciences, (HICSS'05), Hawaii, pp: 1-126. http://direct.bl.uk/bld/PlaceOrder.do?UIN=164821 206\&ETOC $=\mathrm{RN} \&$ from $=$ searchengine

The Star, 2006a. Good Response to e-Filing. The Star. http://thestar.com.my/news/story.asp?file=/2006/4/ $27 /$ nation $/ 14060787 \&$ sec $=$ nation

The Star, 2006b. Manual Return. The Star, pp: 3-4.

The Star, 2009. Amount of Malaysians Choosing efiling up by $30 \%$. Allvoices. http://www.allvoices.com/news/3110620malaysians-filing 